\title{
The complementary roles of liability, regulation and insurance in safety management: theory and practice
}

Citation for published version (APA):

Faure, M. G. (2014). The complementary roles of liability, regulation and insurance in safety management: theory and practice. Journal of Risk Research, 17(6), 689-707.

https://doi.org/10.1080/13669877.2014.889199

Document status and date:

Published: 03/07/2014

DOI:

10.1080/13669877.2014.889199

Document Version:

Publisher's PDF, also known as Version of record

Document license:

Taverne

\section{Please check the document version of this publication:}

- A submitted manuscript is the version of the article upon submission and before peer-review. There can be important differences between the submitted version and the official published version of record.

People interested in the research are advised to contact the author for the final version of the publication, or visit the DOI to the publisher's website.

- The final author version and the galley proof are versions of the publication after peer review.

- The final published version features the final layout of the paper including the volume, issue and page numbers.

Link to publication

\footnotetext{
General rights Owners
rights.

- You may freely distribute the URL identifying the publication in the public portal. please follow below link for the End User Agreement:

www.umlib.nl/taverne-license

Take down policy

If you believe that this document breaches copyright please contact us at:

repository@maastrichtuniversity.nl

providing details and we will investigate your claim.
}

Copyright and moral rights for the publications made accessible in the public portal are retained by the authors and/or other copyright owners and it is a condition of accessing publications that users recognise and abide by the legal requirements associated with these

- Users may download and print one copy of any publication from the public portal for the purpose of private study or research.

- You may not further distribute the material or use it for any profit-making activity or commercial gain

If the publication is distributed under the terms of Article $25 \mathrm{fa}$ of the Dutch Copyright Act, indicated by the "Taverne" license above, 


\title{
The complementary roles of liability, regulation and insurance in safety management: theory and practice
}

\author{
Michael G. Faure** \\ Faculty of Law, METRO Institute, Maastricht University, Maastricht, The Netherlands; \\ RILE, Erasmus University Rotterdam, Rotterdam, The Netherlands
}

(Received 20 December 2013; final version received 3 January 2014)

\begin{abstract}
Liability rules, regulation and insurance have all been proposed in legal and economic theory as instruments to prevent safety risks created by enterprises. Moreover, these rules can also be found in combination in most legal systems. Indeed, liability rules are often advanced as the market solution to safety since they simply allocate a price to unsafe behaviour by signalling that the operator will have to compensate the victims in case of an accident (strict liability) or when the accident was caused through his fault (negligence). Liability rules are thus supposed to have a deterrent effect and should thus promote safety management within enterprises. However, law and economics literature has also clearly pointed at the shortcomings of liability rules in preventing risks: information may be better available with the regulator; the deterrent effect of liability rules can fail as a result of latency, problems of proof and causal uncertainty and insolvency problems may equally limit the deterrent effect of tort rules. That is why many risks posed by industry are often controlled via ex ante safety regulation. However, regulation has its limits as well (more particularly the fact that they can become outdated quickly since they are often static rather than dynamic; that they need a strong enforcement in order to be effective and that regulatory standards may be inefficient as a result of lobbying by private interests). That is why it is suggested that liability rules may still play an important complementary role even in cases where industrial risks are primarily controlled via safety regulation.
\end{abstract}

Keywords: liability; regulation; insurance

\section{Introduction}

Liability rules, regulation and insurance have all been proposed in legal and economic theory as instruments to prevent safety risks created by enterprises. Moreover, these rules can also be found in combination in most legal systems. Indeed, liability rules are often advanced as the market solution to safety since they simply allocate a price to unsafe behaviour by signalling that the operator will have to compensate the victims in case of an accident (strict liability) or when the accident was caused through his fault (negligence). Liability rules are thus supposed to have a deterrent effect and should thus promote safety management within enterprises. However, law and economics literature has also clearly pointed at the shortcomings of liability rules in preventing risks: ${ }^{1}$ information may be better available with the regulator; the

*Emails: metro.institute@facburfdr.unimaas.nl; faure@law.eur.nl 
deterrent effect of liability rules can fail as a result of latency, problems of proof and causal uncertainty and insolvency problems may equally limit the deterrent effect of tort rules. That is why many risks posed by industry are often controlled via ex ante safety regulation. However, regulation has its limits as well (more particularly the fact that they can become outdated quickly since they are often static rather than dynamic; that they need a strong enforcement in order to be effective and that regulatory standards may be inefficient as a result of lobbying by private interests). That is why it is suggested that liability rules may still play an important complementary role even in cases where industrial risks are primarily controlled via safety regulation. $^{2}$

In addition, the deterrent effect of liability rules is often removed through the existence of insurance. Risk-averse enterprises will seek insurance coverage for major hazards. Insurance of course creates the well-known moral hazard problem. However, through an effective risk differentiation, moral hazard can be remedied ${ }^{3}$ and insurance companies could play a positive role in preventing risks caused by industry. ${ }^{4}$ In that way, insurance companies in fact replace the role of liability rules since under full (liability) insurance, prevention is de facto promoted through the control of safety by the insurer rather than through liability rules.

As a result, liability rules, regulation and insurance can, at least in theory, be used in combination to control the risk posed by industry and can thus contribute to safety management. Although the theoretical framework explaining how these particular mechanisms may contribute to safety management is well developed, important questions still remain. One important question relates to the interdependencies between liability rules, regulation and insurance. Theoretical literature often studies these three instruments (and their incentive effect in promoting safety management) separately, whereas in practice, they are often used in combination. This raises the question to what extent and how these various instruments should interrelate in promoting safety management. Should (violation of) regulation for example lead to liability of an operator or should, to the contrary, compliance with regulation free the operator from liability? Moreover, questions can also be asked concerning the interrelationship between regulation on the one hand and (liability) insurance on the other. The question for example can be asked to what extent compliance with regulation can be seen as a condition for insurance coverage and to what extent regulatory standards can hence be employed by insurers in their control of moral hazard. Hence, the question arises as to the optimal combination of and interdependencies between liability rules, regulation and insurance as instruments for promoting safety management.

Moreover, there is increasing empirical evidence showing that to some extent the particular instruments do not always correspond to the theoretical assumptions on which they are based. Liability rules may not always provide optimal deterrence; regulation can in some cases impose suboptimal standards and insurance companies do not always engage in the optimal control of moral hazard as suggested by economic literature. The failure of the optimal application of the particular instruments can lead to dramatic consequences as far as the occurrence of catastrophic industrial incidents is concerned. These empirical insights on the functioning of liability rules, regulation and insurance in the control of safety hazards should be taken into account in order to address the causes of the deficiencies. These empirical insights may, moreover, lead to different policy advice concerning the optimal combination of the various instruments compared to a merely theoretical approach. 
The goal of the proposed paper is therefore to examine, as the title suggests, the complementary role of liability rules, regulation and insurance. In that respect, special attention will be paid to the optimal combination of these instruments, especially taking into account the empirical evidence concerning the way in which these particular instruments have functioned in addressing particular safety hazards.

The way this will be done is by pointing briefly at some of the theoretical insights on the benefits of combining regulation, liability and insurance and at the same time verifying to what extent these benefits are actually realised in practice. Practice in this respect refers both to empirical evidence that would be available as well as to the implementation of those combinations in legal practice. Given the diversity of legal systems, only a few examples to illustrate the points can be provided.

The main point is that, taking into account empirical evidence and some evolutions in the legal system, some remaining challenges both in the field of regulation as well as in the field of (liability) insurance will be identified.

The paper is structured as follows: after this introduction, the joint use of liability rules and regulation will be discussed (Section 2), including the remaining challenges in both domains; next the attention will turn to insurance, but more particularly the combination with liability and regulation (Section 3). Again, a few remaining challenges will be identified. This leads to some conclusions in Section 4, pointing at some potential weak spots in the combination of liability, insurance and regulation.

\section{Liability vs. regulation}

\subsection{Theory}

The theoretical starting point for the choice between liability rules and regulation as devices to give incentives to industrial operators to introduce optimal abatement techniques has been a classic paper by Shavell indicating that when information on optimal abatement techniques is better with government and, if an insolvency problem may arise, when for a number of reasons a liability suit may never be brought, ${ }^{5}$ regulation is generally considered to be more effective to control industrial risks than private law instruments like liability rules. ${ }^{6}$ Indeed, with many industrial risks (especially those created by small and medium size enterprises), information on optimal abatement technologies may be better with government (who can use economies of scale in research and development) and enterprises may also be protected by limited liability (as a result of the corporate structure). This creates potentially an insolvency problem which may seriously reduce the deterrent effect of liability rules. ${ }^{7}$ Moreover, liability rules may be particularly ineffective in cases of uncertainty concerning the relationship between the industrial activity and the harm (causal uncertainty), or when damage would only arise many years after the activity which was at the source of the harm took place (this is referred to as latency or the long-tail character of liability). For those (and many other) reasons, liability rules may often fail to have a deterrent effect, which points to the theoretical superiority of regulation in controlling risks posed by industrial activities.

\subsection{Empirics}

For example, as far as environmental risks are concerned there is substantial empirical evidence of the relative effectiveness of safety regulation, at least when 
compared to liability rules. Dewees demonstrated in various studies that in North America the quality of the environment has improved substantially as a result of regulatory efforts, and not so much in response to legal action in tort. ${ }^{8}$ In a volume summarising the effectiveness of various instruments to prevent accidents, Dewees, Duff and Trebilcock held that the large regulatory efforts to improve the environment have been met with considerable success when measured by the reduction of emissions. ${ }^{9}$ However, they equally stressed that while environmental regulation is a determinant factor in pollutant emissions and ambient concentrations, other non-regulatory factors, such as economic growth and even the weather, also influence environmental quality. ${ }^{10}$ Also the literature on the so-called environmental Kuznets Curve has shown that strengthening the regulatory structure in a country encourages the promotion of environmental quality. ${ }^{11}$

\subsection{Liability and regulation combined?}

\subsubsection{Theory}

Even though according to the criteria just presented, there are strong arguments for controlling risks created by industry through ex ante regulation, in individual cases damage can still arise. The question then arises whether liability under tort can still be used. Is has to be stressed that even though there are many arguments in favour of ex ante regulation, this does not mean that the liability system should not be used any longer for its deterrent and compensating functions. One reason still to rely on the tort system is that the effectiveness of regulation is dependent upon enforcement, which may be one of its weak spots. In addition, the influence of lobby groups on regulation, to which public choice theory has rightly pointed, ${ }^{12}$ can lead to the creation of suboptimal standards in regulation. The same is true when standards are set via permits, in which case governmental agencies can be captured by industry. Moreover, safety regulation, for example via permits, can become rapidly outdated and often lacks flexibility. These are hence all arguments to combine regulation with liability rules, in which case liability can back up weaknesses in regulation. ${ }^{13}$ In theory, liability should therefore have a complementary effect in addition to regulation and more particularly intervene where regulation shows weak spots. The joint use of regulation and liability, however, raises the question how interdependencies between liability rules and regulation should be dealt with at the policy level. ${ }^{14}$

\subsubsection{Violation of regulation and liability}

Taking the easy case first one can question whether a violation of a regulatory standard should automatically lead to a finding of liability. The economic answer is at first blush not straightforward. On the one hand, it could be argued that it depends on whether the regulatory standard is equal to the optimal standard or not. In the case of a regulatory standard being inefficiently stringent, holding industry to comply with this inefficient standard (via liability) would not seem appropriate. ${ }^{15} \mathrm{How}-$ ever, an important reason to introduce regulation in the first place was the assumed informational advantage of the regulatory authority, not only compared to operators (which may not always be the case), but especially compared to the judge. Indeed, the application of a negligence rule (under which the defendant will only be held liable if a certain standard of care was breached) can lead to high information costs for 
the judge who is no expert in risk assessment. The major advantage of a rule, holding that a violation of regulation automatically leads to a finding of liability (also referred to as a negligence per se rule), is that it substantially reduces information costs for the judge. In that case, the judge can rely on information provided by the regulator and has to check merely whether the regulatory standard was complied with by the defendant or not. Moreover, this rule not only has an advantage for the judge but also for potential plaintiffs (victims suffering harm). In general, proving that the harm suffered by the victim was due to a wrongful act of the defending operator may impose high, and potentially even prohibitive, information costs on the plaintiff. A negligence per se rule has the major advantage that the victim merely has to prove that a regulatory standard was breached and that this breach stands in a causal relationship with the harm he suffered. In this way, the victim, moreover, in fact becomes the enforcer of regulation, since the victim has incentives to prove that the regulatory standard was breached. ${ }^{16}$ Here, one can hence find an interesting collaboration between regulation and liability rules. Since most legal systems hold that a violation of regulation automatically leads to a finding of liability (negligence per se $)^{17}$, this on the one hand lowers information costs for both the plaintiffs (victims) and for the judge, but on the other hand also provides incentives for the victim to show that a regulatory standard was breached. In this way, the victim de facto becomes the monitor of regulatory standards and contributes to the enforcement of those standards. This negligence per se system can be found in many legal systems and hence seems to make sense from an economic point of view.

\subsubsection{Compliance with regulation and liability}

Industry will often argue that as long as they have followed regulatory requirements, they should not be held liable any longer in tort. This is often referred to as 'justificative effect of a license' or the 'regulatory compliance defence'.

Again, the question whether industry should still be held liable, even if a regulatory standard has been complied with, merits a balanced answer. Ideally, when the regulator sets objective standards to control risks, weighing costs and benefits in an optimal way, it would not make much sense to allow the judge to 'second guess' efficient agency decisions. ${ }^{18}$ However, that is exactly the problem: there may be many reasons why regulatory agencies do not set efficient standards. One problem is that information at the time of setting standards may be limited or lacking as a result of which the standard can be outdated easily; another issue is that the regulatory standard may be inefficiently lenient as a result of lobbying. Holding polluters still liable even though the regulatory standard was complied with has the advantage that industry will still have an incentive to take all efficient precautions, even if this requires more than just following the licence. In this perspective, liability law can have an important complementary effect to support regulation more particularly when regulatory failure could occur. If industry were only held to comply with regulation and there would be no liability beyond compliance with the regulatory standard, serious under-deterrence would be the result. Thus, when compliance with a regulatory standard will only be considered a minimum, there are liability-avoidance incentives for industry to take additional care if this could still reduce the expected accident costs beneficially. ${ }^{19}$

This idea is followed in many legal systems but not in all. This is why, for example, in the European Environmental Liability Directive no agreement could be reached 
on this issue, as a result of which the question whether compliance with a regulatory standard constitutes an excuse from liability was left to the Member States. ${ }^{20}$ It should be understood, however, that this can have quite important consequences, not only for the scope of liability of industry, but obviously also for the incentives for industry to take precautionary measures that go beyond regulatory standards. A 'compliance with permit defence' - regime basically signals to industry that it only has to comply with regulatory standards and hence removes incentives for investments in research and development to find risk-reducing tools that go beyond the regulatory standard. To the contrary, signalling that operators remain liable notwithstanding compliance with the regulatory standard provides important incentives to operators to adopt all reasonable means to further reduce the accident risk. Obviously, even in the latter regime it does not necessarily mean that operators will always be liable in case an accident happens. This would only be the case in a strict liability regime after harm causation has been shown, but not necessarily under a negligence or fault regime. In the latter case, it would only mean that the judge still has the possibility to verify whether the due care required by the regulatory standard was in fact the optimal standard or whether, given evolutions in research and technology, the efficient standard was in fact higher than what the regulator required from the operator.

\subsection{Remaining challenges}

From the above, it becomes clear that on paper an appropriate combination of regulation and liability could provide optimal safety standards for compliance by industry. Industrial risks would primarily be controlled via efficiently set regulatory standards and liability rules would act as a backup where (for a variety of reasons) regulatory standards would be suboptimal. Regulation and liability would, moreover, optimally interact in the sense that a violation of regulation would automatically be considered a fault in the liability regime, as a result of which regulation informs both the parties and the judge on optimal standards and victims have incentives to enforce the regulation. Moreover, in systems where a regulatory compliance defence is rejected, liability could have an important supplementary effect even when there is compliance with regulation. ${ }^{21}$ However, there remain particular challenges both in regulation and in liability which in some cases endanger the ideal picture.

\subsubsection{Regulatory failures}

A first regulatory failure is related to the well-known fact that regulation of industrial risks may work well for well-known risks where technological evidence is available on the scope of the risks and on the possible abatement technologies. The picture changes when there is uncertainty concerning the riskiness of the activities involved, the potential scope of the damage, or concerning the measures that could be taken to prevent the risks. This has lead to sophisticated debates on principles of risk regulation both in academia and at the policy level. ${ }^{22}$ This literature has indicated how expert evidence should be weighed against opinions of the public at large (including public participation) concerning desirable risk levels and has indicated how, faced with uncertainty, policy-makers should regulate risks. Notwithstanding that important progress has been made in this domain in recent years, uncertainty concerning future risks still may be one of the most important challenges for policy-makers in regulation of industry. ${ }^{23}$ 
A second traditional weakness in public regulation is that its effectiveness is to a large extent dependent upon an effective enforcement and, given high costs of enforcement, actual enforcement may always be lower than optimal. To some extent, empirical studies found that notwithstanding low expected sanctions, compliance with regulations is still high. This phenomenon is referred to as the Harrington paradox. $^{24}$ The reason is that many industrial operators will comply for other reasons than the (low) expected sanctions. Risk aversion may play a role, or lacking information (on low expected sanctions), but also additional sanctioning mechanisms, such as reputation or social norms. However, the latter may be important for complying operators (those who would comply anyway, irrespective of the threat of sanctions). Deterrence may still be necessary for the hard core 'rogues' for whom a threat to reputation or social norms would not provide adequate deterrence. The question arises whether the probability of detection and actual sanctions imposed are always sufficiently high to constitute an effective deterrent, especially for those 'rogues' for whom a 'compliance' strategy may not work.

A third classic issue is that public regulation is issued as a reaction to market failures (more particularly weaknesses in liability rules), but lobbying and rent-seeking activities may lower standards to such a level that a market failure is simply replaced by a regulatory failure. Again, also in this domain, important progress has been made. For example, the insights of Gary Becker, that if it were possible to organise a countervailing power against industry lobbying, a kind of competition between various interest groups could emerge, the result of which may be closer to the optimum than when government is only lobbied by pressure groups representing industry interest, ${ }^{25}$ are also applied in practice. Increasingly, attention is given to transparency and accountability of regulatory agencies (thus increasing the costs or rent seeking $)^{26}$ and increasingly NGOs and other groups representing civil society are allowed to intervene in the standard setting by regulators. Recently, Binder and Neumayer showed that environmental NGOs exert a statistically significant impact on pollution levels. ${ }^{27}$ Their paper provides empirical backing for the fact that public participation and NGO influence can effectively counter industry lobbying (according to the Becker model) and hence make standard setting by administrative agencies more in the public interest. However, this may be a remedy in societies which allow NGO activity and public participation, but not in legal systems where this is still problematic (as this is, for example, the case in some developing countries).

A fourth issue, related to the last mentioned, is that there is an increasing tendency, more particularly given the highly technical character of regulation of industry, to increasingly rely on so-called private regulation. Public-private partnerships or, for example, environmental agreements whereby to a large extent industry itself can fix standards are increasingly advanced as examples of 'smart regulation'. ${ }^{28}$ There are undoubtedly advantages of this model, more particularly due to the potentially lower administrative and information costs. Self-regulation or private regulation may have the benefit that government can use superior information of industry, for example, on optimal abatement technologies. ${ }^{29}$ There are, however, potential dangers and warnings as well. One obvious danger is that industry may in fact dictate the standards to which it will have to comply, and, moreover, the standards may be abused for creating barriers to entry. In addition, there have been recent accounts in which enterprises had adopted so-called self-regulatory, eco audits and environmental management systems and where later nevertheless serious accidents with huge damage occurred, casting obviously great doubts with respect to the 
effectiveness of those self-regulatory models. An important point of attention for future research and for policy-makers is hence how one can optimally use the benefits of private and self-regulation without encountering the unavoidable dangers as well. An important question in that respect is also how self-regulation can be used in a context where the drafters and enforcers of the self-regulation can still be held accountable towards the public at large.

\subsubsection{Liability failures}

Even though there may be many failures in regulation, the same is of course the case for liability as well.

A first obvious issue that we already mentioned before is that liability rules can only play their supplementary function in those legal systems that allow operators to still be held liable even in case of regulatory compliance. This is not always the case.

A second problem (that was already indicated by Shavell as a reason for regulation in the first place) was that liability rules may be particularly weak in the case of so-called long-tail damage (when there is a long time lapse between the tort and the occurrence of the harm), or in the case of causal uncertainty.

In this respect, a problematic aspect that arises is that this was also the first area identified where regulation may be weak as well (uncertainty concerning the risks). The crucial question that has to be asked there is which of the two systems are best able to react speedily, adequately and in a flexible manner to newly emerging risks when they appear. On the one hand, the regulatory system is slow and legislating on particular risky activities (e.g. GMOs) may take a long time, in which meanwhile the risks already emerge. ${ }^{30}$ Liability rules on the other hand have the disadvantage that they are ad hoc and case specific. Hence, more particularly in case of a long time lapse (see e.g. asbestos), liability claims may only follow many years after the harmful activity took place and hence come too late. They do have, however, the advantage that they are more flexible and not necessarily limited to the specific activities being regulated. Moreover, in an optimal world, liability rules and regulation could mutually provide information on emerging risks. New appearing cases (e.g. damage resulting from nanotechnologies) could inform the regulator on emerging risks and the necessity to regulate, whereas new regulation could also provide a basis for new liability claims. However, again practice shows that the ideal world cannot always be found in practice. For example, it is held that the first publications on the potentially damaging effects of the use of asbestos date from long before the Second World War and the first liability cases for asbestos-related diseases already appeared in the 1970s. Nevertheless, in some countries the use of asbestos was only banned many years later. ${ }^{31}$ This may hence be an example of a risk where both liability rules and regulatory intervention came too late.

\section{Insurance, liability and regulation}

Let us now add one additional dimension to the debate and move to the more realistic case where operators are not just exposed to liability, but where their liability is covered through insurance. This allows us to analyse how interdependencies occur not only between liability and regulation (discussed in Section 2) but also between insurance, liability and regulation. 


\subsection{Insurance theory: remedying moral hazard}

Insurance theory has indicated that when liability is removed from the operator as a result of liability insurance, a moral hazard problem emerges. ${ }^{32}$ The question therefore arises how incentives can nevertheless be given to the insured to behave exactly in the same way as if no insurance coverage were available. The literature basically identifies two ways of controlling moral hazard. ${ }^{33}$ One way is to control the insured and to adapt the premiums appropriately (this is the first best solution). The second is exposing the insured still partially to risk (e.g. by imposing a cap on the insured amount or introducing a deductible).

In practice, one will often see a combination of both systems of controlling moral hazard. ${ }^{34}$ There will be some degree of differentiation within the policy conditions, a deductible and an upper limit on coverage. If moral hazard is controlled optimally through an optimal risk differentiation and risk classification, the insured operator will again behave as if no insurance coverage were available. At the same time, insurance has the benefit that the disutility of risk is removed from the insurer. In that case, the incentives to take preventive measures are no longer given by liability rules since the threat to have to pay compensation to a victim is shifted to the insurance company. In that sense, insurance takes over the social function (of improving safety) from liability law. Through the control of moral hazard, the insurer will verify, for example, whether the operator adopted an appropriate risk management programme. This shows that an appropriate control of moral hazard is not only in the interest of the individual insurer, but also of society at large. If there were no efficient control of moral hazard, insurance would on the whole do more harm than good. ${ }^{35}$

\subsection{Interdependencies between insurance and regulation}

There are various ways in which insurance and regulation interact, moreover in combination with liability. We already made clear that with liability insurance, the social function of liability is in fact shifted to the insurer, but the interdependencies go further than that.

\subsubsection{Compulsory liability insurance}

Liability rules can be largely ineffective in cases where the expected magnitude of the harm is larger than the injurer's wealth. In that case, an insolvency problem may arise (also referred to as a judgement proof problem), which will result in underdeterrence. Liability rules can deter only if the operator has money at stake that he can lose. ${ }^{36}$ This may particularly be a problem with smaller and medium size enterprises who are also organised as corporate entities and thus enjoy limited liability. The damage these smaller enterprises can cause can potentially be much larger than their assets, thus creating an under-deterrence problem. Some enterprises are, moreover, well aware of the possibilities of using limited liability and, for example, bring risky assets (like a polluted soil) into a separate legal entity to shield themselves from liability. ${ }^{37}$ In those cases, compulsory insurance may provide an optimal outcome. ${ }^{38}$ Introducing a duty to purchase insurance coverage for the amount of the expected loss is hence a remedy for the under-deterrence problem. Here, one hence can find an optimal combination of liability, insurance and regulation: a regulatory duty (to seek a financial guarantee) is introduced to cover liability of an industrial 
operator. It is in other words regulation (or, for example, a permit) that makes the purchase of a financial guarantee (in practice usually compulsory insurance) mandatory. ${ }^{39}$ However, such a duty to insure should only be introduced when particular conditions are met, i.e. there must be a sufficiently competitive insurance market that is able to cover the risk; the moral hazard problem should be cured and the duty to provide financial security should be formulated in a rather broad manner so that not only insurance but also other financial instruments (bonds, captives or guarantees) can be used. ${ }^{40}$

\subsubsection{Regulation to control moral hazard}

A second example of such an interdependency is that regulatory duties imposed upon operators can of course also be relied upon by insurance companies in the control of moral hazard. Insurers will often demand compliance with permit conditions and regulatory duties as a condition for insurance coverage. In that case, the insurer can use the fact that a decision concerning optimal preventive techniques has been made by a regulatory agency and possibly laid down in an administrative permit. The insurer can hence take advantage of the work of the regulator to control moral hazard. On the other hand, insurers will often go beyond mere regulatory compliance and require, for example, compliance with international guidelines or standards (like ISO norms).

This shows that the control of moral hazard by the insurer also has a benefit for public policy since the insurer in fact becomes a regulatory enforcer (by requiring regulatory compliance) and often even goes beyond regulatory compliance. ${ }^{41}$ BenShahar and Logue even go as far as claiming that insurance can to some extent replace regulation by imposing requirements on the operator. ${ }^{42}$

It is anyway clear that there is an interdependency between regulation and insurance in the control of moral hazard, since on the one hand insurers can rely on the existence of regulation in their control of moral hazard, but on the other hand public policy can also rely on insurers in controlling compliance with regulation (thus making the insurer also the enforcer of regulation) and even to go beyond regulation (by requiring compliance with private standards such as ISO norms).

\subsection{Empirics}

Already in the 1980 s there was some empirical evidence underlining the importance of risk differentiation in motor vehicle insurance. German economists Adams and Finsinger examined differences in motor vehicle insurance between the United Kingdom on the one hand and Germany on the other. ${ }^{43}$ They argue that in the United Kingdom there was a highly competitive insurance market, resulting in insurers competing with good policy conditions to attract good risks and setting differentiated premiums. In Germany, on the other hand, there was a high concentration in the motor vehicle insurance market, reducing the incentives of liability insurers to adequately control moral hazard via an appropriate risk differentiation. They held that this lack of an appropriate control of moral hazard by insurers led ceteris paribus to a substantially higher amount of fatal car accidents on highways in Germany than in the United Kingdom. This research is interesting for various reasons. 
First, it shows the importance of the market structure for the incentives to appropriately control moral hazard: a too high concentration in insurance markets would dilute the incentives to appropriately control moral hazard.

Second, the lack of incentives to control moral hazard in the German motor vehicle insurance market was also created by a statutorily mandatory profit margin on insurance premiums. This created the perverse incentive for German insurers to collect high premiums (and thus have high profits) even if this would increase accident risks.

Third, this early research clearly underscored the relationship between the control of moral hazard and accident risks.

There is some more recent empirical evidence on the control of moral hazard by insurers. Empirical research seems to suggest that moral hazard is more likely to occur in some insurance markets than in others. ${ }^{44}$ Empirical research found evidence of moral hazard for example in the workmen's compensation area. ${ }^{45}$ For other domains, there is less clear evidence of moral hazard. ${ }^{46}$

More disturbing, however, is the question how insurers react to moral hazard. According to the theoretical starting points, one would expect insurers to fight moral hazard by applying an adequate risk differentiation via appropriate risk management tools, clauses in policy conditions, deductibles etc. The disturbing issue is that recent surveys, especially in the works by Baker and Griffith, show that insurers often consider the costs of monitoring the insured during the running period of the contract excessive compared to the expected benefits. ${ }^{47}$ The result is that less energy is spent on monitoring the insured than one would expect on the basis of theory. It is not so clear to what extent this tendency of the (liability) insurers not to monitor their insured is problematic. On the one hand the cost of controlling moral hazard must clearly be set off against the expected benefits; on the other hand, too little effort by the insurance industry may result in an inefficient level of precaution and therefore increase accident risks. ${ }^{48}$

\subsection{Remaining challenges}

Also as far as the relationship between insurance, liability and regulation is concerned, there are a few important remaining challenges:

- A first problem is that in many statutes, often following the implementation of international conventions, a relatively low cap is introduced on the liability of industrial operators. These types of financial limits (caps) can, for example, be found in international conventions on nuclear liability, ${ }^{49}$ but also in conventions with respect to marine oil pollution. ${ }^{50}$ The reason to introduce these caps is often that they are deemed necessary to keep the liability risk insurable. However, the downside of a financial cap is obviously that there is no liability beyond the amount of the cap. To the extent that these caps are set much lower than the average costs of an accident (like this is for example the case in the nuclear liability conventions), ${ }^{51}$ a serious problem of under-deterrence could emerge. An obvious solution would be to disconnect the amount of the liability from the duty to insure. The duty to provide financial coverage (like insurance) could then be limited to an insurable amount, but for the remainder the operator could remain liable without limits. 
- Even though it was just indicated that in case of an insolvency risk, it would be important to impose a duty to seek financial guarantees (like compulsory liability insurance) upon industrial operators, in practice those duties are not always introduced or at least important differences exist between legal systems. For example, substantial mandatory solvency guarantees exist in a country like Belgium, but less so in The Netherlands. The result was that when an explosion of a fireworks factory took place in Enschede, the operator only had (voluntarily purchased) insurance coverage for low amounts. ${ }^{52}$ Since the explosion had blown away half a city, the damage was obviously much larger than the capacity of the operator. Also when six months later a horrible fire took place on New Years Eve in a café in Volendam (The Netherlands), again the voluntary purchased insurance by the operator was by no way sufficient to cover the huge damage caused by the incident. ${ }^{53}$ In both (and many other) cases, the result was that the government intervened to compensate the victims rather than the operator. This, however, means that without mandatory financial guarantees operators are able to externalise harm to society and the corresponding under-deterrence problem continues.

Apparently in some legal systems, there is a reluctance towards the introduction of financial guarantees (probably as a result of effective lobbying by special interests representing industry), not only in The Netherlands but in other legal systems as well. For example, when in France the AZF factory in Toulouse exploded on 21 September 2001, it was a reason for the French legislators to introduce, rather curiously, a mandatory insurance for potential victims of industrial accidents as an add-on to the coverage of first party motor vehicles and housing insurance. ${ }^{54}$ It is, however, in cases of industrial accidents, rather curious to introduce mandatory victim insurance rather than (which would be a more obvious solution both from an efficiency as well as from a fairness perspective) mandatory liability insurance for the operator.

The issue of mandatory financial guarantees could apparently also not lead to harmony in the EU. When the EU environmental liability directive was introduced, attempts were made to accompany the strict liability for environmental damage that the directive introduced with compulsory liability insurance or other forms of financial guarantees. However, divergences between the member states on this issue were so large that the directive could not prescribe anything substantial on that issue, other then that the issue will have to be addressed in the future.

- An argument that is often advanced against the introduction of financial guarantees like compulsory liability insurance is that it would make government too greatly dependent upon the insurance market. By making the activity dependent upon the availability of insurance, insurers would de facto become the licensors of the activity. ${ }^{55}$ This may especially be problematic in cases where insurance markets are not sufficiently competitive but highly concentrated, or where for specific industrial risks insurance coverage would simply not be available. Especially for newly emerging risks, this may be a serious issue. However, it is important in that respect indeed not to be solely dependent upon the commercial (re)insurance market, but also to rely upon alternative compensation mechanisms, other than insurance. In this respect, one could think of bank guarantees, deposits, but also of the creation of captives or risk-sharing agreements (also referred to as pooling) between operators. ${ }^{56}$ 
Precisely given the importance to have guarantees against insolvency, it may be important for government to play a role in stimulating the development of those alternative compensation mechanisms for example with appropriate tax incentives. $^{57}$

- A final challenge is related to the capacity of the (re)insurance market. In some cases, the damage caused as a result of an industrial accident can be of such a magnitude that it easily outweighs the possibility of the traditional (re)insurance market. ${ }^{58}$ This was typically also the case for the terrorism risk, especially after 9/11. The example of terrorism and of the insurance cover for natural disasters in some legal systems provide interesting examples in that respect. One can notice that increasingly governments intervene in the compensation to victims of catastrophic risk by taking a role as reinsurer of last resort. This is for example the case in the terrorism risk where a multi-layered approach is followed and government in fact only backs up the coverage provided by commercial insurers and reinsurers. ${ }^{59}$

The positive experiences gained with those public-private partnerships for the coverage of terrorism and some natural disasters could also be used for the coverage of industrial risks where the capacity of commercial (re)insurance markets would fail.

\section{Conclusion: where are the weak spots?}

The story above highlighted that from a theoretical perspective, there will be an ideal combination of regulation, liability rules and insurance, whereby they optimally interact and all contribute in the public interest to promote safety:

- optimal safety regulation would be set in the public interest and efficiently enforced;

- it would be backed up by liability rules with victims having sufficient access to justice and information to back up safety regulation where regulatory failure would occur;

- the deterrent effect of liability rules would be guaranteed with mandatory solvency guarantees (such as insurance) up to insurable amounts and unlimited liability for the remainder (hence without financial caps);

- the liability insurer (or other provider of solvency guarantees) would effectively control risk management by industry via differentiated insurance policies, thereby relying on public and private safety regulation; and

- public enforcers, private standard setting agencies and liability insurers would thus cooperate in enforcing safety standards.

If this ideal picture were true, all instruments (liability, regulation and insurance) could efficiently collaborate in promoting industrial safety and to some extent liability insurance may even replace regulation. ${ }^{60}$

However, practice may unfortunately look different to the ideal picture of theory and all potential weaknesses both in regulation, ${ }^{61}$ liability rules ${ }^{62}$ and insurance ${ }^{63}$ could come together as well, more specifically:

- liability rules may fail to be effective given the long-tail character of the harm that may only emerge years after the activity; 
- causal uncertainty may inhibit an efficient application of liability rules;

- safety regulation may be absent (e.g. because of uncertainties), may be the result of rent seeking or (unclear) private regulation; moreover, enforcement of the regulation can be lacking as well;

- a mandatory solvency guarantee can be lacking or financial caps are introduced (as a result of which industry can externalise harm to society); and

- insurers may not engage in efficient control of moral hazard.

If all of these weaknesses would accumulate in one particular accident case, this is of course the perfect recipe for disaster. Take the case of the Fukushima nuclear power plant in Japan. ${ }^{64}$ Without going into detail, a few of the disaster recipes may have played a role in this case:

- the initial decision to locate the power plant in an earthquake-prone area is according to Ramseyer the result of the fact that the nuclear operator (Tepco) is able (because the damage will be substantially larger than its own wealth) to externalise harm to the Japanese society; ${ }^{65}$

- in many countries, the nuclear industry is not subject to intensive public safety regulation, but to private regulation based on rather vague principles. To the extent that this is the case in Japan as well, private safety regulation may have been one of the causes of failure;

- safety regulation (or specific permit conditions) apparently failed since they did not prescribe that reserve diesel generators had to be installed at a location where they were not prone to be subject to flooding;

- the company that designed the power plant and decided on the defective location of the reserve diesel generators (General Electric) cannot be held liable since in Japan liability is exclusively channelled to the licensee of the nuclear power plant (Tepco), thus excluding liability of third parties like General Electric. Liability rules hence could not provide incentives to General Electric for a better design of the power plant;

- parliamentary commissions had warned about the location of the plant in an earthquake and tsunami risk area, but apparently these warnings did not lead to subsequent action, probably also because of the importance of the nuclear industry for energy supply in Japan and because of close relationships between the nuclear industry and politicians in Japan; ${ }^{66}$ and

- the operator of the plant, Tepco, only had to provide coverage up to a limited amount; for the remainder it remains in principle liable (without limits) but since the total damage will easily outweigh the financial possibilities of Tepco, de facto the damage is to a large extent externalised to the Japanese government (and hence to the tax payers). As a result of this, liability rules may also fail to have an additional deterrent effect.

The result of this cumulation of recipes for catastrophe could be noticed on 11 March 2011, which once more underscores the importance of an appropriate design of the interdependencies between liability, insurance and regulation.

\section{Notes}

1. See inter alia Brans (2001, 35-64) and Bergkamp (2001, 208). 
2. See Arcuri $(2001,37-45)$.

3. Shavell (1979, 541-562).

4. Abraham (1988, 942-988).

5. For example, because the damage can be widespread, victims can believe damage has natural causes, victims cannot be identified and long latency periods and problems of causation may exist.

6. See Shavell (1984a, 368-371). See also Wittman (1977) and Shavell (1984b).

7. See Shavell (1986).

8. Dewees (1992a, 1992b).

9. Dewees, Duff, and Trebilcock $(1996,315)$.

10. Dewees, Duff, and Trebilcock $(1996,307)$.

11. Esty and Porter (2005, 391-425). See also Faure (2012, 306-307).

12. See inter alia Maloney and McCormick (1982).

13. See on this point inter alia Burrows (1999) and Kolstad, Ulen and Johnson (1990).

14. These issues are highly debated both in the legal and in the law and economics literature. For a discussion from a comparative legal perspective, see the contributions in Van Boom, Lukas, and Kiessling (2007), for evidence from France see Bentata and Faure (2012).

15. Shavell (1984a, 365-366).

16. See Faure and Van den Bergh (1987, 95-114).

17. See Lukas $(2007,455)$ and Van Boom $(2007,429-431)$.

18. Rose-Ackerman (1991, 1992a, 1992b).

19. Burrows (1999) and Kolstad, Ulen, and Johnson (1990, 888-901).

20. See De Smedt (2007) and De Smedt and Faure (2010, 783-808).

21. In his recent thesis, Bentata shows that for example in France in an important number of cases of civil liability, judges in fact impose liability on operators even though they comply with regulation, hence confirming this complementary role of liability rules. See Bentata and Faure (2012).

22. See in the EU for example The Communication of the EU Commission on the Precautionary Principle, COM(2000)1.

23. See for example Wiener (2004) and Vogel (1995).

24. See Harford and Harrington (1991) and Harrington (1988).

25. Becker (1983).

26. See Black $(2008,137-164)$.

27. Binder and Neumayer (2005).

28. Gunningham, Grabosky, and Sinclair (1998).

29. Ogus $(1995,98)$.

30. See on liability risks resulting from GMOs the contributions in Koch (2008).

31. See in that respect the dissertations of Sobczak (2013) and Ruers (2012).

32. See generally Pauly (1968) and Arrow (1963).

33. See generally Shavell (1979).

34. See Baker (1996).

35. See Faure and Hartlief $(2003,108)$ and Shavell (1982).

36. See generally Shavell (1986).

37. Another example constitutes the so-called single ship companies in the maritime area in order to reduce the risk in case of marine pollution. With a single ship company all the operator puts at risk is the value of the ship itself.

38. See for example Jost (1996) and Polborn (1998).

39. See Jost (1996), Polborn (1998) and Skogh (2000).

40. See Faure (2006).

41. See Faure and Hartlief (2003, 110-112) and Ben-Shahar and Logue (2012).

42. Ben-Shahar and Logue (2012).

43. See inter alia Adams (1985), Finzinger, Hammond, and Tapp (1985) and Finsinger (1988).

44. For a summary, see Van Boom (2008) and Chiappori (2000, 371).

45. See inter alia Dionne and St-Michel $(1991,236)$.

46. For a recent summary of the literature, see Avraham (2012, 49-51).

47. See Baker and Griffith (2007a) and Baker and Griffith (2007b). 
48. See Van Boom (2008), number 2.4.

49. For example, the Convention on Third Party Liability in the Field of Nuclear Energy of 29 July 1960 (Paris Convention), 956 UNTS 251 and the Vienna Convention on Civil Liability for Nuclear Damage of 21 May 1963 (Vienna Convention), 1063 UNTS 358.

50. For example, the International Convention on Civil Liability for Oil Pollution Damage (referred to as the CLC or the Brussels Convention).

51. But also seriously criticised. See inter alia Trebilcock and Winter (1997).

52. See further Faure and Hartlief $(2006,218-219)$.

53. Faure and Hartlief (2006, 220-221).

54. See Cannarsa, Lafay, and Moréteau (2006, 88-89).

55. So Monti $(2001,51)$.

56. See for a variety of possible financial security mechanisms Guidance Document 4 of the European Commission concerning the implementation of Directive 2009/31/EC on the Geological Storage of Carbon Dioxide.

57. A problem could arise that today payments of an insurance premium to a commercial liability insurer are tax deductable whereas reserves set aside or contributed e.g. to a captive or to a pooling arrangement may not always get the same treatment.

58. See generally on problems with the supply of disaster insurance Gollier $(2005,13-30)$.

59. See on this role of government as reinsurer of last resort for catastrophes Bruggeman, Faure, and Fiore (2011) and Monti (2012).

60. This was recently proposed by Chicago scholars Ben-Shahar and Logue (2012).

61. Mentioned above in 2.4.1.

62. Discussed above in 2.4.2.

63. Discussed in 3.4.

64. For details, see Nakamura (2012).

65. Ramseyer (2011).

66. Ibid.

\section{References}

Abraham, K. 1988. "Environmental Liability and the Limits of Insurance." Columbia Law Review 88: 942-988.

Adams, M. 1985. Ökonomische Analyse der Gefährdungs- und Verschuldenshaftung [Economic Analysis of Strict Liability and Negligence]. Heidelberg: R.V. Decker's Verlag.

Arcuri, A. 2001. "Controlling Environmental Risk in Europe: The Complementary Role of an EC Environmental Liability Regime." Tijdschrift voor Milieuaansprakelijkheid [Environmental Liability Review] 1-2: 37-45.

Arrow, K. 1963. "Uncertainty and the Welfare Economics of Medical Care." American Economic Review 53: 941-973.

Avraham, R. 2012. "The Law and Economics of Insurance Law - A Primer." The University of Texas School of Law. Law and Economics Research Paper No. 224. http://ssrn.com/ abstract $=1822330$.

Baker, T. 1996. "On the Genealogy of Moral Hazard." Texas Law Review 75: 237-292.

Baker, T., and S. J. Griffith. 2007a. "The Missing Monitor in Corporate Governance: The Directors and Officers' Liability Insurer." Georgetown Law Journal 95: 1795-1843.

Baker, T., and S. J. Griffith. 2007b. "Predicting Corporate Governance Risk: Evidence from the Directors' and Officers' Liability Insurance Market." University of Chicago Law Review 74: 487-544.

Becker, G. S. 1983. "A Theory of Competition among Pressure Groups for Political Influence." The Quarterly Journal of Economics 98: 371-395.

Ben-Shahar, O., and K. D. Logue. April 2012. "Outsourcing Regulation: How Insurance Reduces Moral Hazard." University of Chicago Law School Working Paper. http:// ssrn.com/abstract=2038105.

Bentata, P., and M. G. Faure. 2012. "The Role of Environmental Civil Liability: An Economic Analysis of the French Legal System." Environmental Liability 20 (4): $120-128$.

Bergkamp, L. 2001. Liability and Environment. The Hague: Kluwer Law International. 
Binder, S., and E. Neumayer. 2005. "Environmental Pressure Group Strength and Air Pollution: An Empirical Analysis." Ecological Economics 55: 527-538.

Black, J. 2008. "Constructing and Contesting Legitimacy and Accountability in Polycentric Regulatory Regimes." Regulation and Governance 2: 137-164.

Brans, E. H. P. 2001. Liability for Damage to Public Natural Resources - Standing, Damage and Damage Assessment. The Hague: Kluwer Law International.

Bruggeman, V., M. G. Faure, and K. Fiore. 2010. "The Government as Reinsurer of Catastrophic Risks?" Geneva Papers on Risk and Insurance 35: 369-390.

Burrows, P. 1999. "Combining Regulation and Legal Liability for the Control of External Costs." International Review of Law and Economics 19: 227-244.

Cannarsa, M., F. Lafay, and O. Moréteau. 2006. "France." In Financial Compensation for Victims of Catastrophes, edited by M. Faure and T. Hartlief, 81-118. Vienna: Springer.

Chiappori, P. A. 2000. "Econometric Models of Insurance under Asymmetric Information." In Handbook of Insurance, edited by G. Dionne, 365-393. Boston, MA: Kluwer Academic Publishers.

De Smedt, K. 2007. Environmental Liability in a Federal System: A Law and Economics Analysis. Antwerpen: Intersentia.

De Smedt, K., and M. G. Faure. 2010. "The Implementation of the Environmental Liability Directive." Zeitschrift für Europaïsches Privatrecht 4: 783-808.

Dewees, D. 1992a. "Tort Law and the Deterrence of Environmental Pollution." In Innovation in Environmental Policy, edited by T. H. Tietenberg, 139-163. Cheltenham: Edward Elgar.

Dewees, D. 1992b. "The Comparative Efficacy of Tort Law and Regulation for Environmental Protection." Geneva Papers on Risk and Insurance 17: 446-464.

Dewees, D., D. Duff, and M. Trebilcock. 1996. Exploring the Domain of Accident Law. Taking the Facts Seriously? Oxford: Oxford University Press.

Dionne, G., and P. St-Michel. 1991. "Workers' Compensation and Moral Hazard." The Review of Economics and Statistics 73: 236-244.

Esty, D. C., and M. E. Porter. 2005. "National Environmental Performance: An Empirical Analysis of Policy Results and Determinants." Environment and Development Economics 10: 391-434.

Faure, M. G. 2006. "Economic Criteria for Compulsory Insurance.” The Geneva Papers on Risk and Insurance 31: 149-168.

Faure, M. 2012. "Effectiveness of Environmental Law: What Does the Evidence Tell Us?" William and Mary Environmental Law and Policy Review 36 (2): 293-336.

Faure, M., and T. Hartlief. 2003. Insurance and Expanding Systemic Risks. Paris: OECD.

Faure, M., and T. Hartlief. 2006. "The Netherlands." In Financial Compensation for Victims of Catastrophes: A Comparative Legal Approach, edited by M. Faure and T. Hartlief, 195-226. Vienna: Springer.

Faure, M., and R. Van den Bergh. 1987. "Negligence, Strict Liability and Regulation of Safety under Belgian Law: An Introductory Economic Analysis." Geneva Papers on Risk and Insurance 12: 95-114.

Finsinger, J. 1988. Verbraucherschutz auf Versicherungsmärkte, Wettbewerbsbeschränkungen, staatliche Eingriffe und ihre Folgen [Consumer Protection on Insurance Markets, Restrictions on Competition, Regulatory Interventions and their Consequences]. München: Finsinger.

Finzinger, J., Y. Hammond, and J. Tapp. 1985. Insurance: Competition or Regulation? A Comparative Study of the Insurance Markets in the United Kingdom and the Federal Republic of Germany. London: Institute for Fiscal Studies.

Gollier, Chr. 2005. "Some Aspects of the Economics of Catastrophe Risk Insurance." In Catastrophic Risks and Insurance, edited by OECD, 13-30. Paris: OECD.

Gunningham, N., P. Grabosky, and D. Sinclair. 1998. Smart Regulation. Designing Environmental Policy. Oxford: Clarendon Press.

Harford, J. D., and W. Harrington. 1991. "A Reconsideration of Enforcement Leverage When Penalties Are Restricted." Journal of Public Economics 45: 391-395.

Harrington, W. 1988. "Enforcement Leverage When Penalties Are Restricted: A Reconsideration under Asymmetric Information." Journal of Public Economics 37: 289-295. 
Jost, P. J. 1996. "Limited Liability and the Requirement to Purchase Insurance." International Review of Law and Economics 16: 259-276.

Koch, B. A., ed. 2008. Economic Loss Caused by Genetically Modified Organisms. Liability and Redress for the Adventitious Presence of GMOs in Non-GM Crops. Vienna: Springer.

Kolstad, Ch. D., Th. S. Ulen, and G. V. Johnson. 1990. "Ex Post Liability for Harm vs. Ex Ante Safety Regulation: Substitutes or Complements?" American Economic Review 80: 888-901.

Lukas, M. 2007. "The Function of Regulatory Law in the Context of Tort Law - Conclusions." In Tort Law and Regulatory Law, edited by W. H. van Boom, M. Lukas, and Chr. Kiessling, 449-464. Vienna: Springer.

Maloney, M. T., and R. E. McCormick. 1982. "A Positive Theory of Environmental Quality Regulation." Journal of Law and Economics 25: 99-123.

Monti, A. 2001. "Environmental Risk: A Comparative Law and Economics Approach to Liability and Insurance." European Review of Private Law 9: 51-79.

Monti, A. 2012. "Public-Private Initiatives to Cover Extreme Events." In Extreme Events and Insurance: 2001 Annus Horribilis, edited by Chr. Courbage and W. Stahel, 27-38. Geneva: The Geneva Association.

Nakamura, M. 2012. "11 March Japanese Earthquake, Tsunami and Nuclear Emergency: How Insurance Responded in Post-disaster Recovery." In Extreme Events and Insurance: 2011 Annus Horribilis, edited by Chr. Courbage and W. Stahell, 65-79. Geneva: The Geneva Association.

Ogus, A. I. 1995. "Rethinking Self-regulation." Oxford Journal of Legal Studies 15: 97-108.

Pauly, M. 1968. "The Economics of Moral Hazard: Comment." American Economic Review 58: $531-545$.

Polborn, M. 1998. "Mandatory Insurance and the Judgment Proof Problem." International Review of Law and Economics 18: 141-146.

Ramseyer, J. M. 2011. "Why Power Companies Build Nuclear Reactors on Fault Lines: The Case of Japan." Theoretical Inquiries in Law 31: 457.

Rose-Ackerman, S. 1991. "Regulation and the Law of Tort." American Economic Review, Papers and Proceedings 81: 54-58.

Rose-Ackerman, S. 1992a. "Environmental Liability Law." In Innovation in Environmental Policy, Economic and Legal Aspects of Recent Developments in Enforcement and Liability, edited by T. H. Tietenberg, 223-243. Brookfield, VT: Edward Elgar.

Rose-Ackerman, S. 1992b. Rethinking the Progressive Agenda: The Reform of the American Regulatory States. New York: The Free Press.

Ruers, R. F. March 15, 2012. "Macht en tegenmacht in de Nederlandse asbestregulering [Power and Countervailing Power in Dutch Asbestos Regulations]." Diss., Erasmus University Rotterdam.

Shavell, S. 1979. "On Moral Hazard and Insurance." Quarterly Journal of Economics 93: 541-562.

Shavell, S. 1982. "On Liability and Insurance." Bell Journal of Economics 13: 120-132.

Shavell, S. 1984a. "Liability for Harm versus Regulation of Safety." Journal of Legal Studies 13: $357-374$.

Shavell, S. 1984b. "A Model of the Optimal Use of Liability and Safety Regulation." Rand Journal of Economics 15: 271-280.

Shavell, S. 1986. "The Judgment Proof Problem." International Review of Law and Economics 6: 43-58.

Skogh, G. 2000. "Mandatory Insurance: Transaction Costs Analysis of Insurance.” In Encyclopaedia of Law and Economics II, Civil Law and Economics, edited by B. Bouckaert and G. De Geest, 521-537. Cheltenham: Edward Elgar.

Sobczak, F. January 17, 2013. "Liability for Asbestos Related Injuries." Diss., Maastricht University.

Trebilcock, M., and R. A. Winter. 1997. "The Economics of Nuclear Accident Law." International Review of Law and Economics 17: 215-243.

Van Boom, W. H. 2007. "On the Intersection between Tort Law and Regulatory Law - A Comparative Analysis." In Tort Law and Regulatory Law, edited by W. H. van Boom, M. Lukas, and Chr. Kiessling, 419-448. Vienna: Springer. 
Van Boom, W. H. 2008. "Insurance Law and Economics: An Empirical Perspective." In Essays in the Law and Economics of Regulation - In Honour of Anthony Ogus, edited by M. Faure and F. Stephen, 253-276. Antwerp: Intersentia.

Van Boom, W. H., M. Lukas, and Chr. Kiessling, eds. 2007. Tort Law and Regulatory Law. Vienna: Springer.

Vogel, D. 1995. Trading up: Consumer and Environmental Regulation in a Global Economy. Cambridge, MA: Harvard University Press.

Wiener, J. 2004. "Convergence, Divergence, and Complexity in US and European Risk Regulation." In Green Giants? Environmental Policies of the United States and the European Union, edited by N. J. Vig and M. G. Faure, 73-109. Cambridge, MA: MIT Press.

Wittman, D. A. 1977. "Prior Regulation versus Post Liability: The Choice between Input and Output Monitoring." Journal of Legal Studies 6: 193-211. 